\title{
BRAND AWARENESS AND PREFERENCE TOWARDS QUALCOMM SNAPDRAGON IN MOBILE AMONG CONSUMERS
}

\author{
Dr. S. Saravana Kumar \\ Assistant Professor, Ramaiah Institute of Management Studies, \\ Bangalore, Karnataka, India \\ Dr. S. Murali \\ Assistant Professor, Ramaiah Institute of Management Studies, \\ Bangalore, Karnataka, India
}

\begin{abstract}
Consumers' conscience is satisfied according to their needs and desires, so they choose the product from which they get maximum value and satisfaction. For any business Marketing plays a vital part and advertising being the most important part of marketing. The researchers focused on brand awareness of the American semiconductor and telecommunications equipment company Qualcomm Snapdragon, which designs processors and wireless telecommunications.

As a part of this research process, the researchers focuses not only on brand awareness and preference towards Qualcomm Snapdragon(QS) and also consumers awareness of Qualcomm Snapdragon products, who are their major competitors and how this company can exhibits its USP in the competitive Indian economy. This survey was also conducted to understand the factors influencing the consumers to choose Snapdragon product on their mobile phone, their satisfaction level and to address the gap between consumers need versus their level of satisfaction.

This survey was done through a primary data collection with a deep research of the customer profile and various others factors taking into consideration. Chi Square analysis is done based on responses from 190 respondents out of 220 sample chosen for the study. After thorough analysis some recommendation were offered which would help to know about Brand Awareness and Preference of Qualcomm Snapdragon towards consumers and finally a brief conclusion of the study is drawn.
\end{abstract}

Key word: Qualcomm Snapdragon, brand awareness, Snapdragon products, consumer's awareness of Qualcomm.

Cite this Article: Dr. S. Saravana Kumar and Dr. S. Murali, Brand Awareness and Preference Towards Qualcomm Snapdragon in Mobile Among Consumers, International Journal of Management, 10 (4), 2019, pp. 9-18.

http://iaeme.com/Home/issue/IJM?Volume $=10 \&$ Issue $=4$ 


\section{INTRODUCTION}

A Brand is a distinguishable entity that makes specific promises of value. In its simplest form, a brand is nothing more and nothing less than the promises of value or your product makes. These promises can be implied or explicitly state, but none - the - less, value of some type is promised.

Qualcomm Incorporated is an American multinational semiconductor and telecommunications equipment company that designs and markets wireless telecommunications products and services. It derives from chip making and the bulk of its profit from patent licensing businesses. The company headquarters is located in San Diego, California, United States, and has 224 worldwide locations. The parent company is Qualcomm Incorporated (Qualcomm), which includes the Qualcomm Technology Licensing Division (QTL). Qualcomm's wholly owned subsidiary, Qualcomm Technologies, Inc. (QTI), operates substantially all of Qualcomm's R\&D activities.

Qualcomm is an American multinational semiconductor and telecommunication equipment which makes the processor and wireless telecommunication. It makes the processors in bulk and giving to the other licensing business. This company located in San Diego, California and United States. Its parent companies are Qualcomm Technology Licensing, operates the Qualcomm R\&D activities. It makes product like semiconductors, tracking device, satellite phones, QChat, MedisFLO and so on and it is also make software like operating system, speech codec, FEC codec, Eudora client, Eudora server and so on.

Qualcomm Snapdragon is Set of System on a Chip (SoC) items for cell phones structured and advertised by Qualcomm Technologies Incorporated. It was established in November 2007. It's had models like Snapdragon 400, 700, 600, 800 arrangement just as X arrangement independent modems. A solitary SoC may contain different CPU centers, Graphics Processing Unit (GPU) and others programming and equipment to mind a versatile like Global Positioning System (GPS), camera, motion sensors and Video.

Qualcomm informed its "Krait" microarchitecture in the following the age of Snapdragon SoCs in 2011, allowing every processor center to modify its speed dependent on the gadget's needs. At the 2013 purchaser gadgets appear, Qualcomm presented the first of the Snapdragon 800 arrangement and renamed earlier models as the 200, 400 and 600 arrangement. A few new repetitions have been presented since, for example, the Snapdragon 805,810, 615 and 410. Qualcomm re-branch its exceptional items under the Snapdragon name in December 2014. As 2018, ASUS, HP and Lenovo have started selling workstations with Snapdragon based CPUs running Windows 10 under the names "Constantly Connected PCs", making a passage into the PC advertise for Qualcomm and the ARM engineering.

This paper is mainly to understand the brand awareness and Preference towards Qualcomm Snapdragon in mobile among Consumers. Apart from this, it helps to understand new opportunities in market for improvement of brand awareness and sales towards the consumers in mobile. In this research, data basically collected from Primary and secondary sources, where primary data includes questionnaires, personal interview of customers, survey and many more, on the other hand under Secondary data their magazines, journals, websites and other published report related to the brand awareness. Non- probability sampling method was used to select the respondents and after collecting the data, Chi-square test were used to analyze the following problems.

- Brand awareness problems.

- Factors for unawareness of the product.

- Unfavorable awareness factors.

- Reason for limited awareness in the market (if any). 


\section{Competitors of the Company}
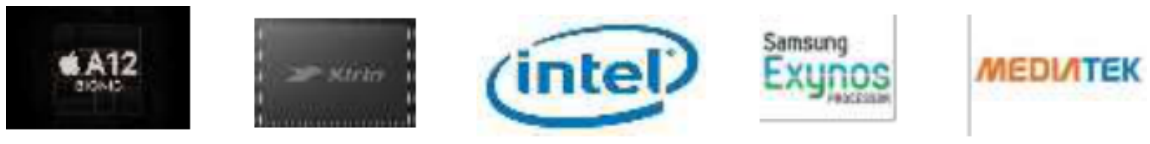

\section{LITERATURE REVIEW}

Review of literature has vital significance with any research work. Due to literature review the possibility of duplication of study can be removed and another height can be selected for the study. The literature review helps researcher to remove boundaries of existing work or may assist to extend predominant study.

Notwithstanding, there are different circumstances where brand mindfulness is likewise critical, for instance in B2B (business to business) showcasing. Here, much lays on the way that the client knows about the organization - and that specific trust fundamentally exists just on the grounds that he knows the organization or its related image. For the reasons for increasingly point by point examinations, brand awareness is separated into three phases: -

- Top of the mind

- Unaided review

- Aided review and acknowledgment

"Top of the mind" implies that instantly recollect the brand, so for them it is in every case rationally present. In this case of "unaided review", a person think about a brand name yet needs some time to thoroughly consider it. This dimension of brand awareness is as yet valuable for organizations, however in circumstances where an acquiring choice must be made rapidly, this sort of brand awareness frequently won't make a difference. At the third stage, "Aided review" or "recognition", individuals don't recall the brand name through their own effort, however will perceive the brand when provoked. This kind of brand acknowledgment is especially helpful when the client has little item information yet has time to make on his buy choice in harmony.

Czyzewski, Andrew (25 Nov 2012) - begins the highlighted that Europe's biggest charging trial begins in London. The drive for the decent plug in network should continue apace, but there is a way. It promises a completely invisible, but near ubiquitous, charging network ask for little in a way of behavior change from petrol vehicle owner. Qualcomm wireless charging is based on principle of magnetic resonance that you can simply drives over the pad and keep charging continuously.

Cristiano Amen (19 Nov 2014) - announced that Qualcomm wants to move out of your pocket into your car, house and wearable. It working on technology to make car "see" and let them "talk" to each other. It's also driving the development of the internet of things, the concept of connecting all kind of objects like lights to clothing to thermostats to stoves.

Steve Mollenkopf (21 Jan 2017) - announce that Qualcomm blast the market share of Apple company. She suggests that Apple is the most innovative company in the world but only for the royal respondents. Because Qualcomm grow day by day increase the products and successful it in last 37 years. They understand that what it should will come in future.

From laptopmag.com (25 June 2018) - It appears that Qualcomm's looking to solve one of the biggest issued that plagued the first Windows laptops that ran on its chip. Sluggish performance. New description to suggest that a supped-up Snapdragon $1000 \mathrm{CPU}$ is in the works, which could provide sufficient speed to complete with system running Intel's mainstream processors. The news comes from the Berlin based WinFuture, which claims that the ARM chips will sport through performance to be compare to Intel's stronger Y - series and 
$\mathrm{U}$ - series $\mathrm{x} 86$ processors. The $\mathrm{Y}$ - series chips are less powerful and $\mathrm{U}-$ series processor is used in more average, everyday laptops.

The best contenders of Qualcomm Snapdragon are Apple bionic chip and Exynos processor. These brands are all inclusive well known for claim mobiles. Qualcomm Snapdragon manufactured its brand awareness among the general population. They can expand the brand awareness of the products with the help of television so it achieves the vast number of respondents. Since numerous respondents did not know the processor and they buy the mobile to see the feature and compare to other mobiles. In this piece of the processor there are many organization giving great performance, value, significant, quality, etc. giving the Qualcomm Snapdragon. They will accompany new system and one of a kind to offering rivalry to other mobile processor. They will improve the issues which they are coming in the Qualcomm Snapdragon.

\section{RESEARCH METHODOLOGY}

\subsection{Problem Statement}

In the developing knowledge-based economy it has become essential to know how much market power lies with the brand name. The study of brand awareness is vital in marketing planning. Customer needs and preferences keep changing where brands finally command customer loyalty.

The genuine side of the problem is to know the acceptance level of the brand awareness towards the Qualcomm Snapdragon processor in mobile. This study will help us to understand the brand buying motives of "Brand Awareness and Preference towards Qualcomm Snapdragon in mobile among Consumers" apart from this, it is to understand the new opportunities to accept this brands and sales towards product in mobiles.

\subsection{Objectives of the Study}

This study has been conducted with the following objectives in mind:

- To study the awareness of customer about Qualcomm Snapdragon.

- To know factor influencing awareness about Qualcomm Snapdragon.

- To study the positioning develop by Qualcomm Snapdragon to create awareness.

- To verify the impact on brand awareness among buyers.

- To identify the factor influencing customer purchase.

\subsection{Purpose of the study}

- To understand the awareness of Qualcomm Snapdragon processor in Bangalore city.

- To know various promotional activities used by Qualcomm Snapdragon processor.

- To understand stimulus, use of company to promote by Qualcomm Snapdragon processors.

- To suggest Qualcomm Snapdragon processor after thorough analysis.

\subsection{Data Collection}

This survey is conducted using both primary and secondary data. Using a well- structured questionnaire provided by the researchers about Qualcomm Snapdragon in collecting the primary data. The common factor in all varieties of the questionnaire method in this survey on verbal response to questions, written or oral. The questionnaire was well designed which related to preference and brand awareness of Qualcomm Snapdragon towards consumer on different features like preference, price, quality, performance, effectiveness of the brands etc., and easy to read and understand to all range of respondents to the sample chosen. The primary data . 2 . 
ollected by directly interacting with the respondents. The respondents were contact at students, teachers, and businessman and mobile showrooms and so on. The data was collected by interacting with 190 respondents who filled the questionnaire and gave me the required necessary information. All the person interviewed were in the age above 20 years. Secondary data consist of data retrieved from College Library database, such as articles, journals, literatures in addition to books from library or retrieve from Google Books and Google Scholar. These materials helped to identify the factors required for this research study. The researcher checked and organized the collected data daily for the completeness and accuracy. The data subjected to suitable statistical analysis using chi square test.

\subsection{Sampling technique}

The non - probability, convenient sampling technique was used for easy and affordable collection of data, suiting the geographical proximity, accessibility, and availability of the subjects in Bangalore City.

\subsection{Hypothesis of the study}

Null Hypothesis (H0) - Consumers are not aware of Qualcomm Snapdragon and their own prefer while buying mobile in Bangalore city.

Alternative Hypothesis (HA) - Consumers are aware of Qualcomm Snapdragon and their own prefer while buying mobile in Bangalore city.

\section{DATA ANALYSIS}

\subsection{Purpose of using mobile}

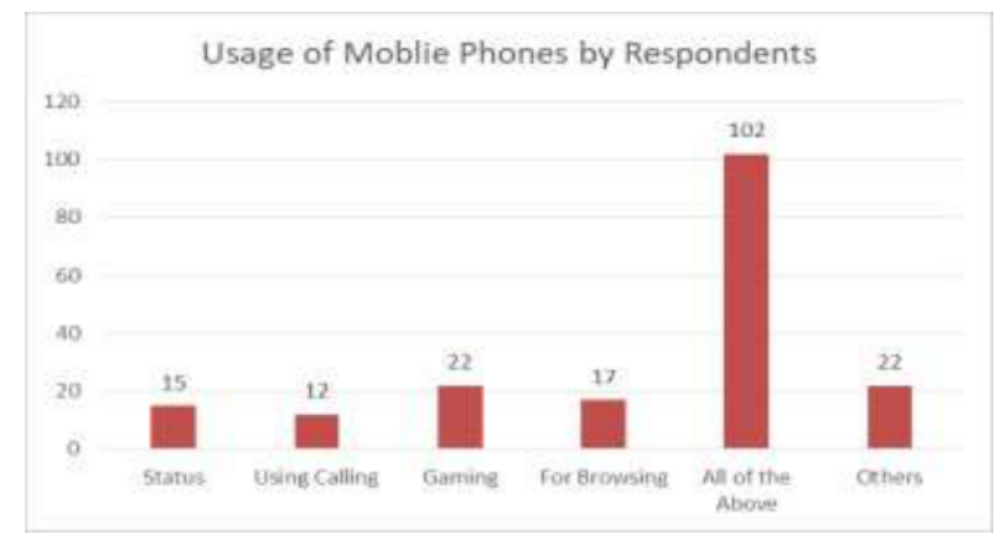

Figure 4.1 Purpose of using mobile

When the respondents was asked about that what are the usage purpose for buying mobile, 102 respondents replied that factor of buying mobile is All of the above and 22 respondents replied that that factor of buying mobile is Gaming and Another factor and 17 respondents replied that that factor of buying mobile is For Browsing and 15 respondents replied that that factor of buying mobile is for Status and 12 respondents replied that that factor of buying mobile is for using calling. Henceforth, through the analysis it was seen that 102 respondents buying mobile phones for various purposes in Bangalore city. 


\subsection{Awareness about the processor in your mobile}

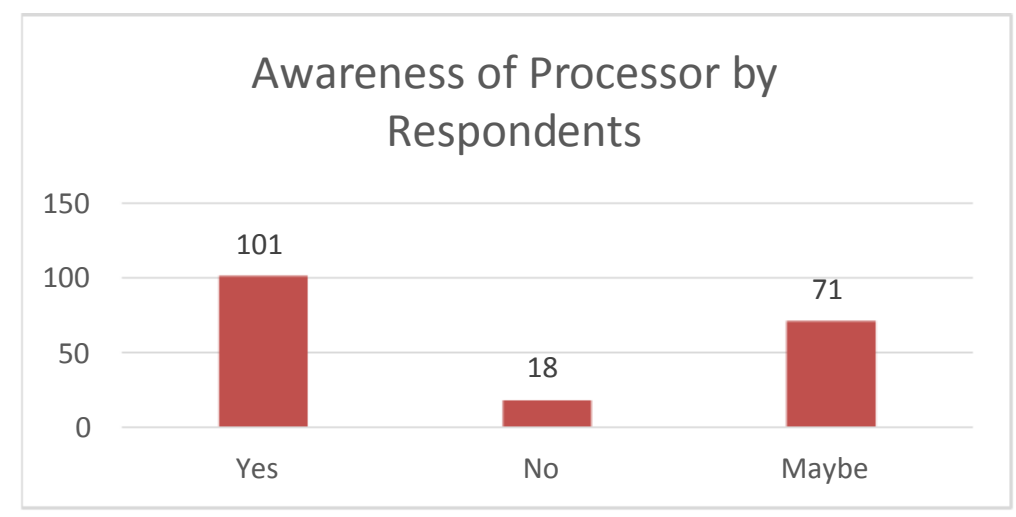

Figure 4.2 Awareness level of Processor used

When the respondents was asked about that do you know about processor in your mobile, 101 respondents replied that they know the processor in mobile and 71 respondents replied that they probably know the processor in mobile and 18 respondents replied that they do not know the processor in mobile. Henceforth through the analysis it was seen that 101 respondents know the processor used in mobile in Bangalore city.

\subsection{Hypothesis Testing}

\begin{tabular}{|c|c|c|c|c|c|c|}
\hline & $\begin{array}{c}\text { Strongly } \\
\text { agree }\end{array}$ & Agree & Neutral & Disagree & $\begin{array}{l}\text { Strongly } \\
\text { disagree }\end{array}$ & TOTAL \\
\hline Battery life & 105 & 55 & 21 & 2 & 7 & 190 \\
\hline $\begin{array}{l}\text { Liquid cooling } \\
\text { tech }\end{array}$ & 77 & 72 & 27 & 7 & 7 & 190 \\
\hline $\begin{array}{l}\text { Hanging } \\
\text { problem }\end{array}$ & 83 & 54 & 36 & 11 & 6 & 190 \\
\hline Heating issue & 65 & 67 & 39 & 10 & 9 & 190 \\
\hline $\begin{array}{l}\text { Quick charge } \\
\text { support }\end{array}$ & 64 & 63 & 40 & 11 & 12 & 190 \\
\hline $\begin{array}{l}\text { Charging } \\
\text { duration }\end{array}$ & 61 & 64 & 41 & 9 & 15 & 190 \\
\hline $\begin{array}{l}\text { Gaming } \\
\text { performance }\end{array}$ & 81 & 48 & 43 & 8 & 10 & 190 \\
\hline $\begin{array}{l}\text { Graphics card } \\
\text { dedicated }\end{array}$ & 76 & 55 & 37 & 10 & 12 & 190 \\
\hline $\begin{array}{l}\text { Graphics } \\
\text { quality }\end{array}$ & 80 & 58 & 31 & 6 & 15 & 190 \\
\hline Dual camera & 71 & 64 & 30 & 13 & 12 & 190 \\
\hline $\begin{array}{l}\text { Coordinate } \\
\text { with software }\end{array}$ & 83 & 61 & 23 & 13 & 10 & 190 \\
\hline $\begin{array}{l}\text { Multitasking } \\
\text { support }\end{array}$ & 80 & 64 & 23 & 11 & 12 & 190 \\
\hline $\begin{array}{l}\text { Smoothly } \\
\text { playback }\end{array}$ & 85 & 53 & 33 & 7 & 12 & 190 \\
\hline $\begin{array}{l}\text { High definition } \\
\text { video support }\end{array}$ & 85 & 54 & 30 & 9 & 12 & 190 \\
\hline $\begin{array}{l}\text { High definition } \\
\text { display } \\
\text { resolution }\end{array}$ & 76 & 61 & 35 & 8 & 10 & 190 \\
\hline $\begin{array}{l}\text { Overall } \\
\text { performance }\end{array}$ & 83 & 61 & 30 & 7 & 9 & 190 \\
\hline TOTAL & 1255 & 954 & 519 & 142 & 170 & 3040 \\
\hline
\end{tabular}


Chi Square test - Chi square test is one of the important tests developed to test hypothesis. It is used to determine between the expected frequencies and the observed frequencies in one or more categories. It is represented by $\left(\mathrm{X}^{2}\right)$. The formula chi square test is: -

$\mathrm{X}^{2}=\sum(\mathrm{O}-\mathrm{E})^{2} / \mathrm{E}$

Where,

$\mathrm{O}$ - Observed frequencies E - Expected frequencies

Null Hypothesis (Ho) - Consumers are not aware of Qualcomm Snapdragon and they won't prefer while buying mobile in Bangalore city.

Alternative Hypothesis (HA) - Consumers are aware of Qualcomm Snapdragon and prefer for Qualcomm brand while buying mobile in Bangalore city.

From the above table the calculated Chi square value $=74.42723$

Number of rows $=16$; Number of columns $=5$; Degree of Freedom $=60$

Hence at $5 \%$ Level of Significance the Tabled Chi Square Value $=79.08$

Since, the calculated value is less than table value so null hypothesis is accepted, and alternative hypothesis is rejected.

Therefore, Consumers are not aware of Qualcomm Snapdragon and their own prefer while buying mobile.

\subsection{Intermediate Conclusion}

According to hypothesis testing it is seen that the null hypothesis is accepted which means that a greater number of consumers are not aware about Qualcomm Snapdragon processor used in mobile phones through this research. They purchase mobile mainly for status as well as looking into other specifications like battery backup, camera pixel etc., Some respondents have knowledge about the mobile processor which they purchase mobile according to its measure the performance and its processor to see the benchmark, battery performance, playing games, camera and so on.

\section{FINDINGS}

As mentioned the sample size was potentially 220 respondents, but a usable set of response of 190 was achieved, yielding a response rate of $86.36 \%$ of these 190 responses, 91 respondents use mobile phone for selfie, gaming, and aware about performance, high screen resolution and others. 102 respondents are buying just for status quo, calling, browsing and others. 101 respondents knew the processor used in mobile.

When the respondents were asked regarding various purpose of having a good processor

- 105 respondents strongly agree that battery life of mobile and 55 respondents agree that battery life of mobile will be improved using a right Processor.

- 83 respondents were strongly agree that hanging problem of mobile is less and 54 respondents were agree that hanging problem of mobile is less.

- 67 respondents were agreed to that heating issue on mobile is less and 65 respondents are strongly agree from heating issue on mobile will become less.

- 64 respondents are strongly agree that quick charge support in mobile is good and 63 respondents are agree that quick charge support in mobile is good.

- 64 respondents are agree from charging duration of mobile is good and 61 respondents are Strongly agree from charging duration of mobile is good.

- 81 respondents are strongly agree gaming performance of mobile is good and 48 respondents are agree gaming performance of mobile is good. 
- 76 respondents are strongly agree graphics card dedicated in game in mobile is good and 55 respondents are agree graphics card dedicated in game in mobile is good.

- 80 respondents are strongly agree that graphics quality in game on mobile is good and 58 respondents are agree that graphics quality in game on mobile is good.

- 71 respondents are strongly agree that dual camera is supporting in mobile is good and 64 respondents are agree that dual camera is supporting in mobile is good.

- 80 respondents are strongly agree and 64 respondents agreed to Multitasking support in mobile is good.

- 85 respondents are strongly agree and 53 respondents agree that their mobile is smoothly support playback.

- 76 respondents are strongly agree and 61 respondents were agree to that high definition display resolution support in mobile is good.

- 83 respondents are strongly agree to overall performance in mobile is good and 61 respondents are agree to overall performance in mobile is good.

- 145 respondents are aware of Qualcomm Snapdragon out of 190 respondents

- 65 respondents are getting information about Qualcomm Snapdragon processor through Internet and 49 respondents get through their friends.

- 110 respondents were generally said that awareness on Qualcomm Snapdragon may effect consumer buying behavior over mobile.

\section{CONCLUSION}

The Brand awareness is an important factor for any company, because it can influence purchase decisions in many contexts. The brand name is very important in what are described as "low involvement situations" where the buyer takes little account of a product in terms of its pricing or other considerations. In such situations, most consumers reach for the "tried and tested" product

- meaning a well-known name and brand. As customers, they buy a lot of things every day. We buy, not only after having pre-assumption about the product but also having nothing. Needs must be fulfilled. Customers are the leaders of the business, not the company. The customer will decide to make a product success or not. They are the key players. So that every companies are running behind the customer offering them large priorities and their needs. Building brands, quality, and image is the short cut to it. Majority has a brand-oriented life. If anyone satisfied with the brand, so it continues with its same. In such time every brand had to try to best to put awareness about it.

Survey was done in and around Bangalore through questionnaire taking 190 respondents into consideration. From this survey got valuable suggestion, opinion and views of the customers. Qualcomm Snapdragon is quite known to respondents. It can improve some issues like heating problem, graphics quality, and performance and so on. It can make unique things so consumers can get attract to buy the mobiles with Qualcomm Snapdragon. Qualcomm Snapdragon had built its brand awareness among the respondents. They can increase the brand awareness of the product with the help of advertising so it reaches the large number of respondents. Because many respondents did not know the processor and they purchase the mobile to see the specification and compares to other phones. It can take advantage of social media, merge the other mobile company to increase the brand and making a blog post that are keyword optimized to ask to solve the problem. It can merge with another mobile company and opt or ingredient marketing so it increases the brand awareness and respondents know about this Qualcomm Snapdragon processor. 


\section{REFERENCES}

[1] Aaker, "Measuring brand equity across products and markets," California Management Rev, 1991

[2] Aaker D.A, "Building strong brands", Hillsdale, NJ: Lawrence Erlbaum Associates, 1992

[3] Aaker, D.A, "Measuring brand equity across products and markets", California Management Rev, 1996

[4] Dr. A. Irin Sutha, An Analytical Study on Social Network As A Tool of Marketing and Creating Brand Awareness in the Present Challenging World of Business. Journal of Management, 5(6), 2018, pp. 58-63.

[5] Blumenthal, D. and Bergstrom A.J.," Brand councils that care: Towards the convergence of branding and corporate social responsibility", Brand Management, 2003

[6] R. Punniyamoorthy \& B.Parthiban, "An Investigation On Brand Awareness In Fast Moving Consumer Goods With Special Reference To Orphanages In Chennai Region", International Journal of Management (IJM), Volume 6, Issue 1, January (2015), pp. 268-279.

[7] Chaudhuri, A. and Holbrook M.B.," The chain of effects form brand trust and brand effect to brand performance: The role of brand loyalty", Journal of Marketing., 65(2), 2001, pp 8193.

[8] Chen A.C.H, "Using free association to examine the relationship between the characteristics of brand associations and brand equity", Journal of product and brand management, 10(7), 2001, pp 439-451.

[9] De Chernatony, L. and McWilliam G, " The varying nature of brands as asset”, International journal of advertising, 8(4), 1989, pp 339-449

[10] Farquhar," Recognizing and measuring brand assets", Marketing science institute, Cambridge, MA, 1991, pp 91-119

[11] Ami Dilham, Fivi Rahmatus Sofiyah and Iskandar Muda, The Internet Marketing Effect on the Customer Loyalty Level with Brand Awareness as Intervening Variables. International Journal of Civil Engineering and Technology, 9(9), 2018, pp. 681-695.

[12] Farquahar, P.H., Herr P.M," The dual structure of brand associations”, In Aaker, D.A., Biel, A.Eds. Brand equity and advertising: Advertising's Role in Building Strong Brands, 1993, pp 263-280

[13] Feldwick, P," What is brand equity anyway and how do you measure it", Journal of the Marketing Research Society, Vol 38, No 2, 1996,

[14] Gremler, D. and Brown S.W," The loyalty ripple effect: appreciating the full value of consumers", International Journal of Service Industry Management, 10(3), 1999, pp 271-293

[15] Johansson, "Assessing the impact of country of origin on product evaluation: a new methodological perspective", Journal of Marketing Research", Vol. 22, No. 4, 1985, pp. 388-396

[16] Keller KL," Conceptualizing, measuring and managing customer-based brand equity", Journal of Marketing, Vol. 57, No. 1 (Jan., 1993), pp. 1-22

[17] Kotler, Philip," Marketing Management", The Millennium Edition, Upper Saddle River, Prentice Hall, 2000

[18] Kotler, Philip and Keller Kevin L, "Marketing Management", 12th edition, Upper Saddle River, NJ: Prentice Hall, 2006

[19] Lassar, W.," Measuring customer-based brand equity", Journal of Consumer Marketing, Vol. 12 No. 4, 1995, pp. 11-19.

[20] Leuthesser," Defining, measuring and managing brand equity: A conference summary, 1988

[21] Nigel F. Piercy (1996), "The effect of customer satisfaction measurement: the internal market versus the external market", Vol. 14 No. 4, 1996, pp. 9-15. 
[22] Olson, J.C. and Jacoby, J, "Cue utilization in the quality perception process", In Venkatesan, M. Ed. Proceedings of the third annual conference of the association for consumer research, association for consumer research, Chicago, IL, 1972

[23] Peter, J.P. and J.C. Olson,, "Consumer behavior" Vol 5, 1993

[24] Pitta, D.A. and Katsanis, "Understanding brand equity for successful brand extension", Journal of Consumer Marketing, Vol. 12 No. 4, 1995, pp. 51-64.

[25] SHOCKER, Allan; SRIVASTAVA, Rajendra Kumar; and RUEKERT, Robert W. Challenges and Opportunities Facing Brand Management: An Introduction to the Special Issue, Journal of Marketing Research. 31, (2), 1994, 149-158

[26] Arthur Rooney, J, "Branding: a trend for today and tomorrow", Journal of Product \& Brand Management, Vol. 4 No. 4, 1995, pp. 48-55.

[27] Thakor, M, "Brand origin: conceptualization and review", Journal of Consumer Marketing, Vol. 13 No. 3, 1996, pp. 27-42

[28] Zeithami, V.A., "Consumer perceptions of price, quality and value: a means-end model and synthesis of evidence", Journal of Consumer Marketing, Vol. 52, No. 3 (Jul., 1988), pp. 222

\section{AUTHOR(S) BIBLIOGRAPHY}

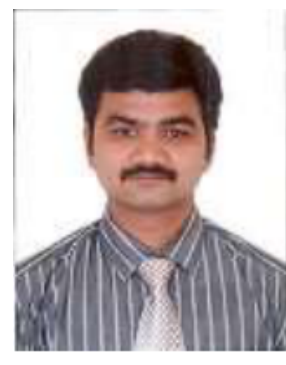

\section{Dr. S. Saravana Kumar}

Assistant Professor

Ramaiah Institute of Management Studies

Bangalore, Karnataka

M: (+91) 7204146145

E: s.sarvankumar@gmail.com

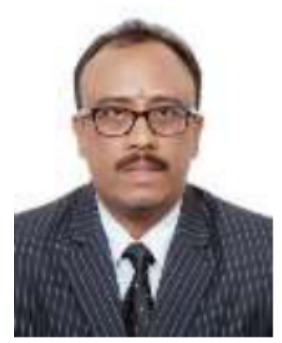

\section{Dr. Murali. S}

Assistant Professor

Ramaiah Institute of Management Studies

Bangalore, Karnataka

M: (+91) 9886022691

E: smphd2009@gmal.com 